\title{
Reconstruction Of Legal Policy On Decency Crime In Indonesia Based On Pancasila Value (LGBT Rehabilitation Institute For Children)
}

\author{
Cucuk Kristiono $^{1}$
}

\begin{abstract}
YKPN survey results showed that there are about 4000-5000 gay in Jakarta. Gaya Nusantara estimates there are 260.000 of the 6 million residents of East Java is Gay. Gays registered as members of the gay community in Indonesia there are 76.288. While Oetomo estimate, there is $1 \%$ of the Homosexual community in Indonesia. Connecting with LGBT victims rehabilitation treatment in children by agency or entity that has not been regulated in Article 292 of the Criminal Code following criminal sanctions if not carried out rehabilitation. Juridical empirical approach is used in hopes obtained a clear and complete picture of the background and the ins and outs of why the implementation of the children rehabilitation of LGBT's victims urgent to be done and set in article 292 of the Criminal Code in the form of additional verse. Considering article 292 of the Criminal Code did not regulate and discusses how the continuation of children as LGBT's victim and only focus on criminal prosecution against the perpetrators only. This sort of thing happens because the regulations have not explicitly regulate this issue. LGBT in Indonesia, including the diversion of moral and immoral acts in the category, but in the regulation of fixed elements deemed equal before the law properly human. Because justice remains true for all citizens with regard to the Pancasila values.

Keywords: Reconstruction; Rehabilitation; LGBT; Children; Pancasila Value.
\end{abstract}

\section{Introduction}

Jones and Hesnard descibe Lesbian is a sexual orientation towards same sex (female), while gay is a sexual orientation towards same sex (male). Lesbian itself has two types differentiated which Butch and Femme. Butch is a masculine women who desire to imitate men (this type take on the role of men in a lesbian relationship). Femme is a feminine fear of man (this type take on the role of women in lesbian relationships). While Gay has two types also are the Top and Bot. Top is the man who groomed and macho (the type that takes role as men in relationships of gay). Bot is a feminine male (type who takes on the role of women in relation of gay) ${ }^{2}$.

Many factors affect the incidence of the Homosexual itself arises from family factors and environmental factors. Usually family factors are more likely in the lack

\footnotetext{
${ }^{1}$ Indonesian Police and Student' s Doctor of Law, Sultan Agung Islamic University in Semarang, email: cucukkristiono11@gmail.com

${ }^{2}$ Anthon F. Susanto , 2004, Wajah Peradilan Kita: Konstruksi Sosial tentang Penyimpangan, Mekanisme Kontrol dan Akuntabilitas Peradilan Pidana, Rafika Aditama, Bandung, Indonesia, p. 209
} 
of the role of parents in children or cases of divorce, violence, even domestic abuse. As a result, a child can be traumatized. Severe traumatic often caused by past events of a child. As an example, can be attributed to the behavior of parents on child molestation or rape case against her daughter's father. These factors usually cause the child to be afraid to interact with the opposite sex. In addition, environmental factors in which a person feels comfortable and more interested in the same sex rather than the opposite sex ${ }^{3}$.

Approximately $5 \%$ or less of the adult population is classified as an active bisexual, who had sexual intercourse with sex during the previous year. Based on initial observation the researchers did to some laymen and also homosexuals, both are equally difficult to identify a bisexual ${ }^{4}$, The informant stated that one of men who look macho, masculine, and is also a playboy, could not guarantee that he is a true heterosexual. Conversely, men who have a gentle nature, graceful, not necessarily a homosexual. This proves that a person who has an interest in the same sex can not be seen from the way they dressed and also their behavior alone ${ }^{5}$, Based on preliminary observations of researchers against one of the informants bisexual, in matters relating to this kind of bisexual people there are dealing with a true homosexual, and there is also a bisexual relationship with each other in order to keep each other's secrets to each other awake. In running lesbian relationship, they will show to the public like an ordinary friendship or companionship. Society's view of deviation behaviors and religious teachings to make them feel like should resist impulses that exist within them to meet the psychological needs as well as their biological6.

\section{Research Methods}

This is a qualitative research with the approach method in this study juridical empirical. This approach is used because of problems that will be discussed in a normative law with due regard to existing regulations and the Pancasila values ${ }^{7}$.

\footnotetext{
${ }^{3}$ Marjono Reksodiputro, 1994, Hak Asasi Manusia Dalam Sistem Peradilan Pidana, Kumpulan Karangan Buku Ketiga, Pusat Pelayanan Keadilan Dan Pengabdian Hukum Lembaga Kriminologi Universitas Indonesia, Jakarta, p.76

${ }^{4}$ Nugraha, Iskandar P., dan Maimunah Munir, 2011, Dinamika Kehidupan Seksual Kelompok LSL di Jayapura, Papua, p. 99-124.

${ }^{5}$ J. C, Chrisler, 2010, Handbook of Gender Research in Psychology. Volume 1: Gender research in general and experimental psychology, p. 486.

${ }^{6}$ T. Altilio, 2011, Oxford Textbook of Palliative Social Work, p. 380.

${ }^{7}$ Sutopo. H.B. 1998. Metodologi Penelitian Hukum Kualitatif Bagian II, UNS Press, Surakarta, p. 265
} 


\section{Results And Discussion}

In Article 292 of the Criminal Code version of R. Susilo said: "Adults who commit obscene acts with minors of the same sex, being known or reasonably should she thought, it's immature, was jailed for 5 years old". In this chapter contains two drawbacks, the first, this article only prohibits homosexual acts between an adult and a child who is kind, but does not prohibit homosexual acts among adults, secondly, in this article also did not mention the rehabilitation efforts of the government through the establishment of the Agency or institutions for LGBT victims of these children including no criminal sanctions for implementing the negligent rehabilitation do it ${ }^{8}$.

During this act of rehabilitation of victims of child prostitution in the LGBT has been done by the Social Affairs Ministry, but on the basis of the appointment of the Criminal Investigation Police who happened to be dealing with LGBT cases to children. In this case there is space handling of victims who have not been regulated in the Criminal Code related to the rehabilitation of children as LGBT's victim by the government therefore necessary to set up the Agency or Institution specially appointed to deal with the rehabilitation of children as LGBT's victim, so without having appointed to carry out the rehabilitation of victims LGBT children, even if necessary the Institute or the agency if it does not carry out rehabilitation or negligent conduct rehabilitation, it can be criminally 9 .

\subsection{Article 292 of the Criminal Code}

Article 292 of the Criminal Code which reads adults who commit obscene acts with minors of the same sex, being known or reasonably should she thought, it has not grown it, was jailed for the duration of 5 years, only formulate criminal sanctions for perpetrators of criminal acts perform obscene acts against same-sex child victims, and does not deal with fellow adult offenders. While rehabilitation for children as LGBT's victim are also not regulated in article 292 of the Criminal Code especially criminal sanctions if it does not perform well at all rehabilitation has not been set. So there is a vacancy in article 292 of the Penal Code which need to be filled gradually, especially on how to implement the rehabilitation for children as LGBT's victim.

\subsection{Investigations}

The probe is a series of actions taken by the investigator to search for and collect evidence, the evidence that makes light of the offenses occurred and locate

\footnotetext{
${ }^{8}$ S.J., Hary Susanto, 2003, “Wisata Seks: Tinjauan Moral”, Journal Center for Tourism Studies of Gadjah Mada University.

${ }^{9}$ http://www.kpai.go.id/berita/kpai-kasus-lgbt-pada-anak-kian-mengkhawatirkan, accessed 20 November 2018
} 
suspects. LGBT actors in investigations conducted by Police events that arise generally in the form of the Gay sex parties involving dozens of people, among them there are children so that in its investigation will separate those where children and adults. It is adjusted in the implementation of article 292 actors LGBT that can be punished if they do it to children, whereas in the case that occurs mixing between actors LGBT children by perpetrators of LGBT adults are taking turns, however, which can be used as a suspect only adult offenders who do it only to children only. In this investigation an investigator is required to synchronize information observant in their testimony against their deviant sexual behavior linkage to the children who participate are secured in order to comply with Article 292 of the Criminal Code ${ }^{10}$.

\subsection{LGBT}

LGBT is a Lesbian, Gay, Bisexual, and Transgender by definition is, Lesbian is one of the same-sex sexual orientation is a woman, while Gay sex sexual orientation is a male. The Bisexuals are people whose sexual orientation to the opposite sex and same-sex and Transgender are people who have a gender identity or gender expression that differs from the sex. Transgender people are also sometimes referred to as a transsexual person if he wanted medical assistance for the transition from one sex to the other sex.

Indonesian society with its eastern culture still considers that LGBT people are those who deviate, so that LGBT people are still hesitant to open themselves to the public. Most LGBT people present themselves as heterosexual, this was done so that LGBT people can hang out comfortably in a variety of social activities in a society.

One form of the application of the condition of this community is the establishment of several NGOs such as Swara Srikandi in Jakarta, LGBT Gaya Nusantara, LGBT Arus Pelangi, and Lantern Sahaja also Indonesian Gay Society in Yogyakarta. In addition, it also emerged and facebook chat facility that made room for each other to know and recognize. This tool is used as a medium to share stories and of course a partner search event. The evidence above is one example of the development of the homosexual community in the present ${ }^{11}$.

Many factors affect the incidence of LGBT people themselves arise from family factors and environmental factors. Usually family factors are more likely in the lack of the role of parents in children or cases of divorce, violence, even domestic abuse. As a result, a child can be traumatized. Severe traumatic often caused by past events of a child. As an example, can be attributed to the behavior of

\footnotetext{
${ }^{10}$ A. Gumilang, 1993, Pengetahuan Tentang Tehnik dan Taktik Penyidikan, Angkasa, Bandung, p. 98

${ }^{11}$ Spillane, James J., 2003, “Etika Bisnis dan Industri Seks Sebagai Kegagalan Pasar Bebas", Journal Center for Tourism Studies Gadjah Mada University.
} 
parents on child molestation or rape case against her daughter's father. These factors usually cause the child to be afraid to interact with the opposite sex. In addition, environmental factors in which a person feels comfortable and more interested in the same sex rather than the opposite sex.

\subsection{Children As LGBT's Victims}

a. Understanding Children According to the Code of Penal (Penal Code) can not be found in the Criminal Code clearly the definition of the child, but is simply a definition of "minors (minderjarig)", as well as some of the definitions that are part or element of the definition contained child in some articles. As in Chapter IX, which provides one element of the notion of children in article 45 , which reads ${ }^{12}$ :

"In prosecuting the minors (minderjarig) for committing before the age of sixteen, the judge may determine, ordered that the guilty be returned to their parents, guardians or caregivers, without any criminal or ordered that the guilty be submitted to the government, without any criminal ie if the act constitutes a crime or one of the violations." So in the article 45 of the Criminal Code then the children are defined as minors when the 16-year-old before.

b. Understanding Children According to Act No. 1 of 1974 on Marriage does not regulate directly benchmarks when someone is classified as a child, but it is implicit in article 6, paragraph (2) which contains a provision requirement of marriage for those who have not yet reached 21 years old found consent of both parents. Furthermore regulated in Article 7 paragraph (1), which contains the minimum age limit to be married to a man is 19 (nineteen) years and women 16 (sixteen) years.

c. Understanding Children According to Act No. 39 of 1999 on Human Rights in Article 1 paragraph 5 that every human being below the age of 18 (eighteen) years old and unmarried, including an unborn child if it is in his interest.

d. Understanding Children under Act No. 23 of 2004 on the Elimination of Domestic Violence is implied in Article 2, paragraph 1, which states that the scope of the households in the legislation include husband, wife, and children. So there is no age limit of the child while the child is still a household setting so she called the child.

e. Understanding Children According to Act No. 21 Of 2007 concerning the Eradication of Trafficking in Article 1 paragraph 5 that someone over the age of 18 (eighteen) years, including the unborn child

\footnotetext{
${ }^{12}$ Ali Wisnubroto, 2002, Praktek Peradilan Pidana (Proses Persidangan Perkara Pidana), PT. Galaxy Puspa Mega, Jakarta, p. 154
} 
f. Understanding Children According to Act No. 35 of 2014 on the Amendment of Act No. 23 of 2002 on Protection of Children in Article 1 paragraph 1 that a person who has not aged 18 (eighteen) years, including an unborn child.

\subsection{Reconstruction Of Legal Policy On Crime Of Decency In Indonesia Based On Pancasila Value (LGBT Rehabilitation Institute For Children As Victim)}

This action is a brilliant idea and enough to fill a legal vacuum especially those regulations regarding LGBT and how to enforce in Indonesia. Institutions LGBT Children's Rehabilitation will be a place and a process to help the victims of LGBT especially children who need medical treatment to achieve a psychological or physical abilities psychological, and social maximum. Here, the doctor must approach that will help the patient or the patient to cope with physical or psychiatric disorder. This kind of an approach is increasingly recognized and make LGBT Children's rehabilitation into a specialized field that is separate from the hospital. Time will run for the patient and outpatient treatment is a very useful program for patients in the early stages. Patients or rehabilitation usually suffer from low self-esteem or a lack of a positive outlook on life, and therefore in the therapeutic psychology plays a big role in the rehabilitation program LGBT Children ${ }^{13}$.

\section{Conclusion}

Of this regulation should regulate and protect child victims of LGBT through the reconstruction of the legal acts of wanton given the absence of laws or regulations that govern the issue of LGBT in Indonesia, including by setting up rehabilitation institutions, so they are not frustrated and equity Pancasila capable realized.

\section{Bibliography}

[1] Anthon F. Susanto , 2004, Wajah Peradilan Kita: Konstruksi Sosial tentang Penyimpangan, Mekanisme Kontrol dan Akuntabilitas Peradilan Pidana, Rafika Aditama, Bandung, Indonesia.

[2] Marjono Reksodiputro, 1994, Hak Asasi Manusia Dalam Sistem Peradilan Pidana, Kumpulan Karangan Buku Ketiga, Pusat Pelayanan Keadilan Dan Pengabdian Hukum Lembaga Kriminologi Universitas Indonesia, Jakarta,.

[3] Nugraha, Iskandar P., dan Maimunah Munir, 2011, Dinamika Kehidupan Seksual Kelompok LSL di Jayapura, Papua.

\footnotetext{
${ }^{13}$ Yesmil Anwar \& Adang, 2008, Pembaruan Hukum Pidana, Reformasi Hukum Pidana, Grasindo, Jakarta, 2008, p. 32
} 
[4] J. C, Chrisler, 2010, Handbook of Gender Research in Psychology. Volume 1: Gender research in general and experimental psychology.

[5] T. Altilio, 2011, Oxford Textbook of Palliative Social Work.

[6] Sutopo. H.B. 1998. Metodologi Penelitian Hukum Kualitatif Bagian II, UNS Press, Surakarta.

[7] S.J., Hary Susanto, 2003, "Wisata Seks: Tinjauan Moral”, Journal Center for Tourism Studies of Gadjah Mada University.

[8] http://www.kpai.go.id/berita/kpai-kasus-lgbt-pada-anak-kianmengkhawatirkan, diakses 20 November 2018

[9] Gumilang, 1993, Pengetahuan Tentang Tehnik dan Taktik Penyidikan, Angkasa, Bandung.

[10] Spillane, James J., 2003, “Etika Bisnis dan Industri Seks Sebagai Kegagalan Pasar Bebas", Journal Center for Tourism Studies Gadjah Mada University.

[11] Ali Wisnubroto, 2002, Praktek Peradilan Pidana (Proses Persidangan Perkara Pidana), PT. Galaxy Puspa Mega, Jakarta.

[12] Yesmil Anwar \& Adang, 2008, Pembaruan Hukum Pidana, Reformasi Hukum Pidana, Grasindo, Jakarta, 2008. 